\section{Pacific Northwest}

National Laboratory

Operated by Battelle for the

U.S. Department of Energy

\title{
Nanoparticle Sensors for Biological Medicine
}

\author{
A Tillman \\ 11 [9dG HV]
}

August 2005

Prepared for the U.S. Department of Energy under Contract DE-AC05-76RL01830 


\title{
DISCLAIMER
}

This report was prepared as an account of work sponsored by an agency of the United States Government. Neither the United States Government nor any agency thereof, nor Battelle Memorial Institute, nor any of their employees, makes any warranty, express or implied, or assumes any legal liability or responsibility for the accuracy, completeness, or usefulness of any information, apparatus, product, or process disclosed, or represents that its use would not infringe privately owned rights. Reference herein to any specific commercial product, process, or service by trade name, trademark, manufacturer, or otherwise does not necessarily constitute or imply its endorsement, recommendation, or favoring by the United States Government or any agency thereof, or Battelle Memorial Institute. The views and opinions of authors expressed herein do not necessarily state or reflect those of the United States Government or any agency thereof.

\author{
PACIFIC NORTHWEST NATIONAL LABORATORY \\ operated by \\ BATTELLE \\ for the \\ UNITED STATES DEPARTMENT OF ENERGY \\ under Contract DE-AC05-76RL01830
}

Printed in the United States of America
Available to DOE and DOE contractors from the Office of Scientific and Technical Information,
P.O. Box 62, Oak Ridge, TN 37831-0062;
ph: (865) 576-8401
fax: $(865)$ 576-5728
email: reports@adonis.osti.gov

\begin{abstract}
Available to the public from the National Technical Information Service, U.S. Department of Commerce, 5285 Port Royal Rd., Springfield, VA 22161 ph: (800) 553-6847 fax: $(703) 605-6900$ email: orders@ntis.fedworld.gov online ordering: http://www.ntis.gov/ordering.htm
\end{abstract}

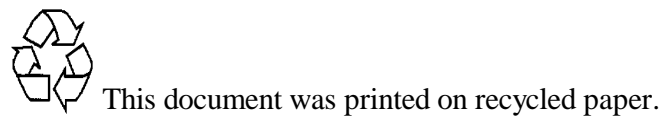




\title{
Nanoparticle Sensors for Biological Medicine
}

\author{
A Tillman \\ NN Bridges
}

August 2005

Prepared for the U.S. Department of Energy under Contract DE-AC05-76RL01830 


\title{
Nanoparticle Sensors For Biological Medicine
}

\author{
Ameer Tillman \\ Office of Science, Science Undergraduate Laboratory Internship (SULI) \\ Washington State University \\ Pacific Northwest National Laboratory \\ Richland, Washington
}

August 5, 2005

Prepared in partial fulfillment of the requirements of the Office of Science, U.S. Department of Energy Science Undergraduate Laboratory Internship(SULI) Program under the direction of Novella Bridges At Pacific Northwest National Laboratory.

Paricipant:

Signature

Research Advisor:

Signature 
Nanoparticle Sensors For Biological Medicine.AMEER TILLMAN (Washington State University Pullman,WA,99163) NOVELLA BRIDGES ( Pacific Northwest National Laboratory Richland WA 99352)

Our work is to focus on making nanoparticles that will be used as a non -invasive method to monitor intracellular trafficking and the transfection of genes. The nanoparticles characterize gradients in oxygen tension and gene expression that occur in the biofilms. The nanoparticles are made by a few different procedures such as the Ormosil and Sol gel pebble formation. The Ormosil formation makes silica particles which are used for gene delivery. This gene delivery can deliver antibiotics or any of the other medicines that could help to kill these biofilms, once something is found that can kill them these will be really useful. These nanoparticles also determine where and how much oxygen there is in the biolfilms. This can show you how bacteria are respiring and functioning and allows you to optimize conditions so you can, for example, prevent corrosion, enhance bioremediation, or enhance chemical production. 


\section{INTRODUCTION}

Biofilms are surface-attached structured communities that are encased by an extra polymeric slime (EPS) matrix. Bacteria are also in close connection with these structures they exchange certain materials like DNA and signaling molecules. These materials are linked to the biofilms and can be dangerous. The biofilm lifestyle can contribute to disease, and beneficial to chemical productions processes. Biofilms on surfaces cost the nation billions of dollars last year with damage of equipment, energy loss, and medical infection. It also offers opportunities for positive effects, such as biofiltering industrial water to keep it clean, and forming biobarriers to protect soil and groundwater from contamination. The negative of Biofilms is what concerns us they are almost impossible to get rid of. The antibiotics it takes to kill them will usually kill a human who is infected with one the diseases cause by biofilms. As of now there are many different methods being used to try and understand these biofilms. We believe to have the most effective method which is using nanoparticle sensors as a non - invasive method to understand the characteristics of these biofilms.

Our work is to focus on making nanoparticles that will be used as a non -invasive method to monitor intracellular trafficking and the transfection of genes. The nanoparticles characterize gradients in oxygen tension and gene expression that occur in the biofilms. The nanoparticles are made by a few different procedures such as the Ormosil and Sol - gel pebble formation. The Ormosil formation makes silica particles which are used for gene delivery. This gene delivery can deliver antibiotics or any of the other medicines that could help to kill these biofilms, once something is found that can kill them these will be really useful. Using Sol gel- pebble formation there will be 
particles formed that will be used to characterize the gradients in oxygen tension and gene expression inside the biofilms.

\section{MATERIALS AND METHODS}

We used all chemicals as received. The chemicals included in the Sol- gel formation $\mathrm{Ru}(\mathrm{II})$ dye $(1129.20 \mathrm{MW})$ at $0.4 \mathrm{mM},(4.6 \mathrm{mg})$ into $6 \mathrm{~mL}(4.74 \mathrm{~g})$ of ethanol. The Ruthenium dye is measured in small plastic tubes. Ethanol is weighed by pipetting into $25 \mathrm{~mL}$ polyethylene scintillation vials. Another option is to make a solution that is $\sim 10 \mathrm{mg}$ Ruthenium(II) dye in $1 \mathrm{~mL}$ ethanol and add ethanol to give a volume of $4.6 \mathrm{mg}$. Weigh ammonia water (concentrated) $3.9 \mathrm{~mL}$ (3.84g) by pipetting into a plastic vial and pouring into vial with Ruthenium in ethanol. We also used $3 \mathrm{~g}$ Polyethylene glycol monomethylether (PEG) in the solution, and then stirred at a speed of 6 on the stir plate for 15-30 minutes. $0.5 \mathrm{~mL}$ of TEOS is then added to the solution one drop every 5 seconds; it is then stirred for one hour at room temperature.

The filtering then takes place with the solution to collect the particles. The first filter is through Amicon 100k Da membranes at 10-20 psi pressure then the filter is rinsed with two $180 \mathrm{~mL}$ rinses of water. The appearance of the filtrate is noted, because color indicates the presence of excess dye that is removed. We next remove the filter with particles and place it into a beaker; $180 \mathrm{~mL}$ of water is added and then ultrasonicated for 10-15 minutes to reignite particles. This filtration through a 5 micron filter will remove large clusters of the particles. We save the filtrate if it is cloudy. It is then ran through the 
ultrafiltration process one more time filter to capture the particles. The filter paper is then dried overnight.

After drying, a piece is cut out of each filter paper for scanning electron micrograph (SEM) pictures. Particles are scraped off of the ultrafiltration filter into plastic micro centrifuge tubes and labeled. After the pictures are taken from the SEM shown in figure 1 , we analyze them by taking an average of 20 particles.

The Ormosil particle formation which is used for gene delivery (based on Koo9 etal. Anal. Chem. 2004, 76, 24982505) is performed by using a $50 \mathrm{~mL}$ round bottom flask or beaker. Add $31 \mathrm{~mL}$ of water, a large stir bar and $38 \mu \mathrm{L} \mathrm{HNO3.} \mathrm{Heat} \mathrm{the} \mathrm{mixture} \mathrm{to}$ $62.5^{\circ} \mathrm{C}$ use at a Corning speed of 9 . This usually takes 20 minutes to heat the solution. Added next is the $0.1 \mathrm{~mL}$ of PTMS $(0.016 \mathrm{M})$ with vigorous stirring 20 minutes long. Next $6 \mathrm{~mL}$ of ammonium hydroxide is added at once, it is stirred for 1-2 hours or until the solution becomes milky. The amount of time at which cloudiness occurs can vary with every experiment. We now add the hydrophobic dyes in the solvents, an example of this is $6.8 \mathrm{e}-7$ moles Dio dye ( $120 \mu \mathrm{L}$ of a $0.5 \mathrm{mg} / \mathrm{ml} 5: 2$ solution of ethanol: THF). The Dio and $\mathrm{DiR}$ which is another hydrophobic dye are both light sensitive so the round bottom must be covered in aluminum foil. With the hydrophobic dyes comes the $0.2 \mathrm{~mL}$ of $\operatorname{MTMS}(0.047 \mathrm{M})$ with stirring and let this sit for one hour. Rinse twice with $180 \mathrm{~mL}$ of water. Rinse twice with $180 \mathrm{~mL}$ ethanol. The dyes are more soluble in ethanol so ethanol works better to remove excess dye. Monitor the appearance of the particles and the filtrate while rinsing to see if there is excess dye being removed.

Suspend the particles again in the ultrafiltration filter with $180 \mathrm{~mL}$ of $1: 2$ solution of water: ethanol or ethanol and Sonicate the mixture for 10-15 minutes. Filter through 
large $5 \mu \mathrm{m}$ filter to get rid of large particles. Note whether filtrate is cloudy indicating that particles are passing through the filter. Filter the particles with ultrafiltration filter to collect sample or microcentrifuge into micro tubes to collect sample. It is easier to collect the Ormosil particles by microcentrifuging because the particles are more hydrophobic and have static which makes them harder to get into tube with just scraping the filter. In cases where we are using a lot of dye it is necessary to suspend the particles more than once, and then perform the ultrasonication, and filter again through a $5 \mu \mathrm{m}$ filter. After drying we cut a piece of each filter paper for SEM.

\section{RESULTS}

The particles that were generated using the Sol - Gel procedure are shown in Figure 1. Our goal is to aim for the particles to be uniform in shape and size on the filter. In each of these pictures the particles are measure one by one to get an average of size. Figure 2 and 3 show results from the Ormosil procedure. Both of these particles aggregated to the center of the filter. These particles were difficult to measure because they aggregated to the center of the filter. These particles cannot be used to do accurate testing on biofilms. Figure 4 is an example of the Ormosil procedure when your procedure is finished. We have not found any real reason why some particles turn out better than others it is just what happens.

Figures 5 and 6 are pictures of actual particles that will be injected into biofilms. The particles in figure 5 and 6 were scrapped off of the ultrafiltration filter and placed into tubes to be analyzed just like you see in the figure.

\section{DISCUSSION AND CONCLUSION}


In order for particles to be used to help us find out more about biofilms they must be uniform and do not aggregate so you have seen in some of the figures. With all of the particles I have made the next thing to be done is for the particles to be analyzed. The person who analyzes them can then see if they will be used for gene delivery and characterizing gradients. With this work we have come closer to our goal of understanding biofilms and eventually to find a way to get rid of their negative forces.

\section{ACKNOWLEDGMENTS}

This research was done at the Pacific Northwest National Laboratory in Richland Washington. I am grateful to the U.S. Department of Energy, Office of Science for the opportunity to participate in the SULI program. It has been a great opportunity for me to broaden my horizons with science, a great encouragement for me to learn more. I want to thank Barbara Tarasevich, who started me on this project .She has displayed a great deal of patience and understanding to maximize my learning experience this summer. I would also like to give a special thanks to my mentor Novella Bridges for the knowledge, patience, and professionalism, she has really been a person I can look up to, and she has shown me how to succeed at a national laboratory.

\section{REFERENCE}

[1] Hao Xu, Jonathan W. Aylott, Raoul Kopelman, Terry J. Miller, and Martin A Philbert , "A Real- Time Ratiometric Method for the Determination of Molecular Oxygen Inside Living Cells Using Sol - Gel Based Spherical Optical Nanosensors with Applications to Rat C6 Glioma". Anal. Chem. 2001, 73, pp.4124-4133

[2] Indrajit Roy, Tymish Y. Ohulchanskyy, Dhruba J. Bharali, Haridas E. Pudavar, Ruth A. Mistretta, Navjot Kaur, and Paras N. Prasad. " Optical tracking of organically modified silica nanoparticles as DNA carriers: A nonviral, nanomedicine approach for gene delivery". Institute for Lasers, Photonics, and Biophotonics Jan.2005 pp. 279-284 
[3] G.H. Bogush and C.F. Zukoski IV "Studies of the Kinetics of the Precipitation of Uniform Silica Particles through the Hydrolosis and Condensation of Silicon Alkoxides" Journal of Colloid and Interface Science, Vol .142 March 1991 . pp 1-16 


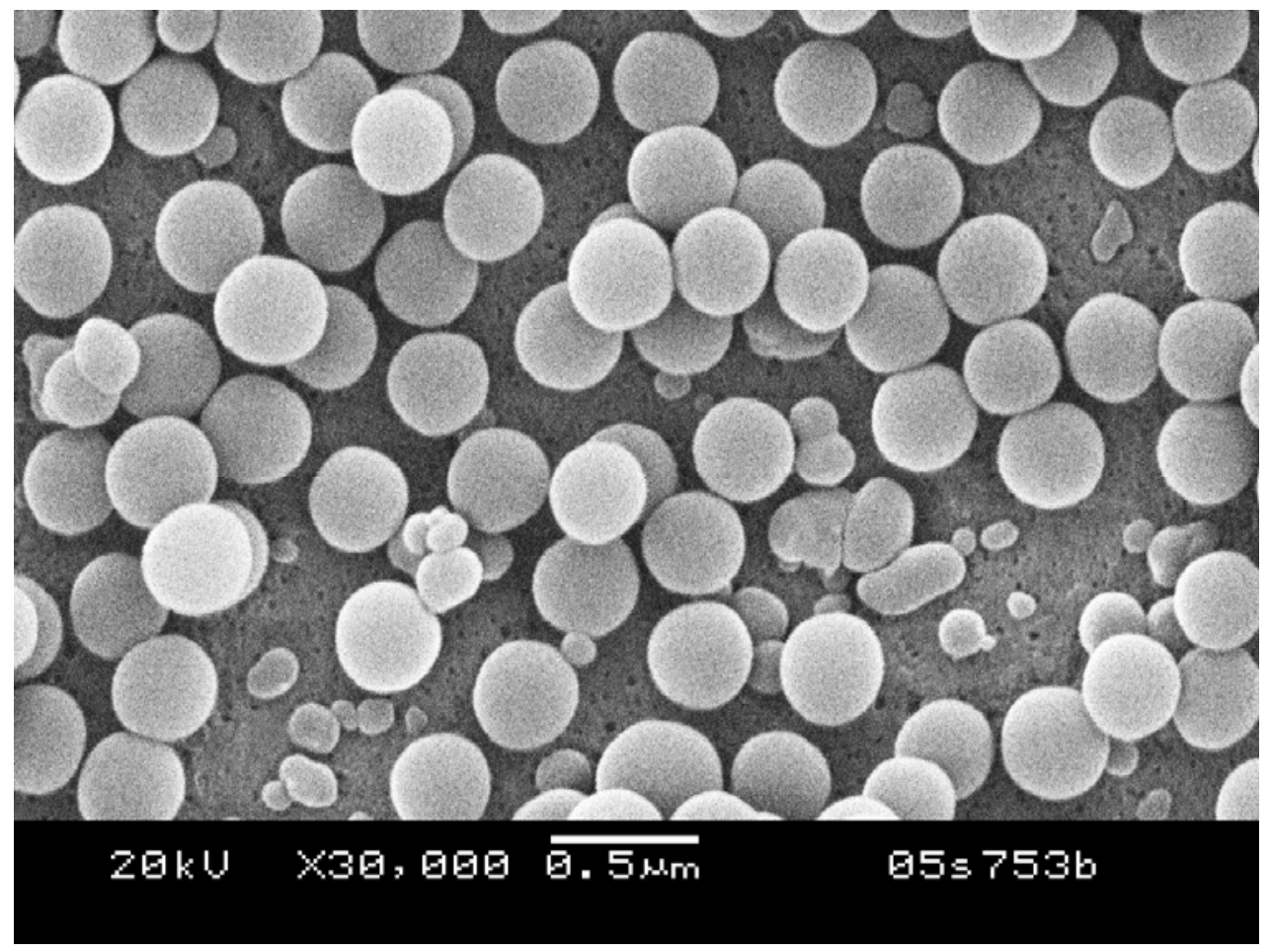

Figure 1. Particles from the Sol- Gel pebble procedure, these particles are somewhat uniform but not exactly what we are looking for in uniformity.

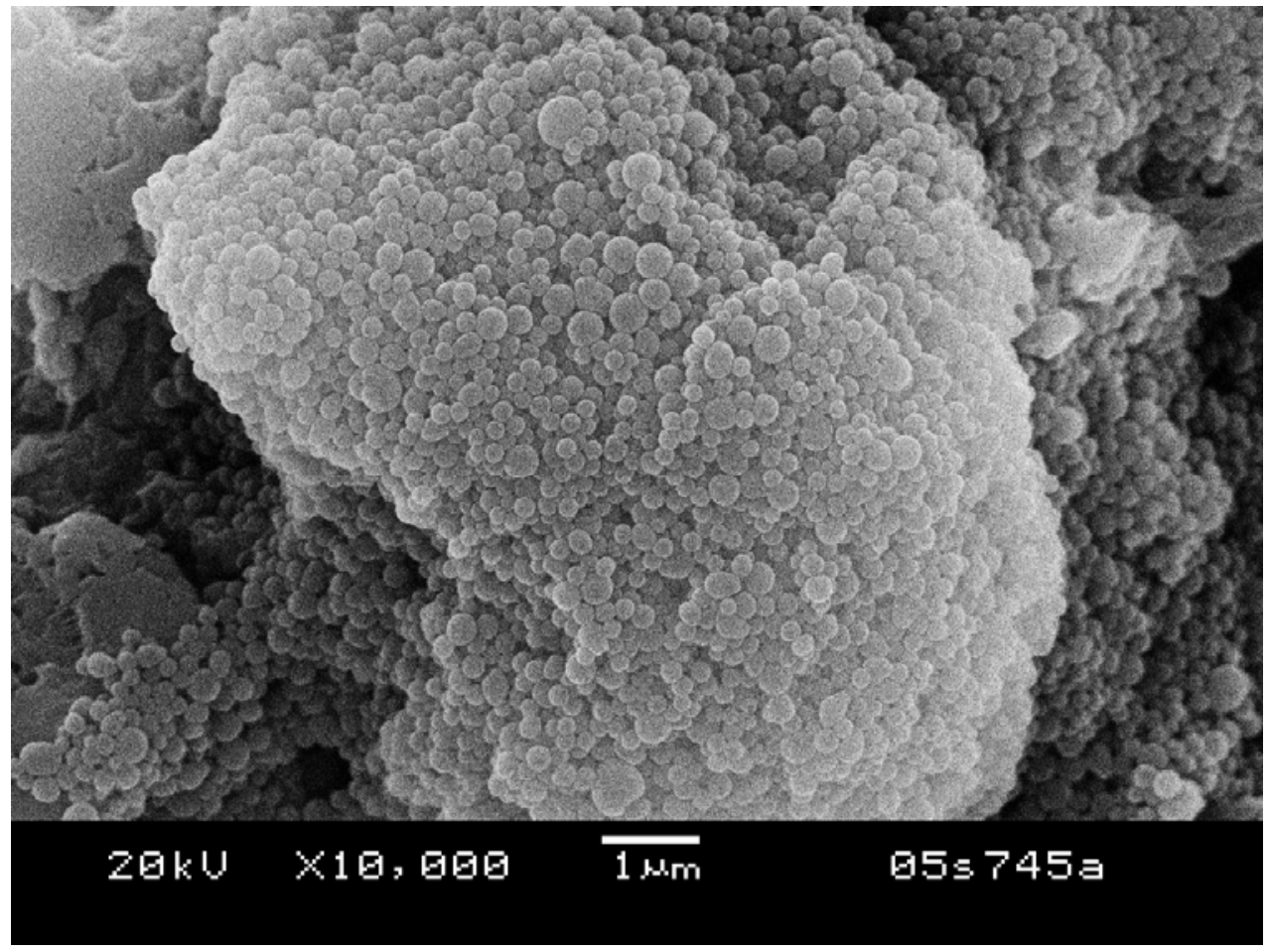

Figure 2. Example of particles that aggregated together this usually comes from a high amout of dye. This is also an ormosil procedure. 


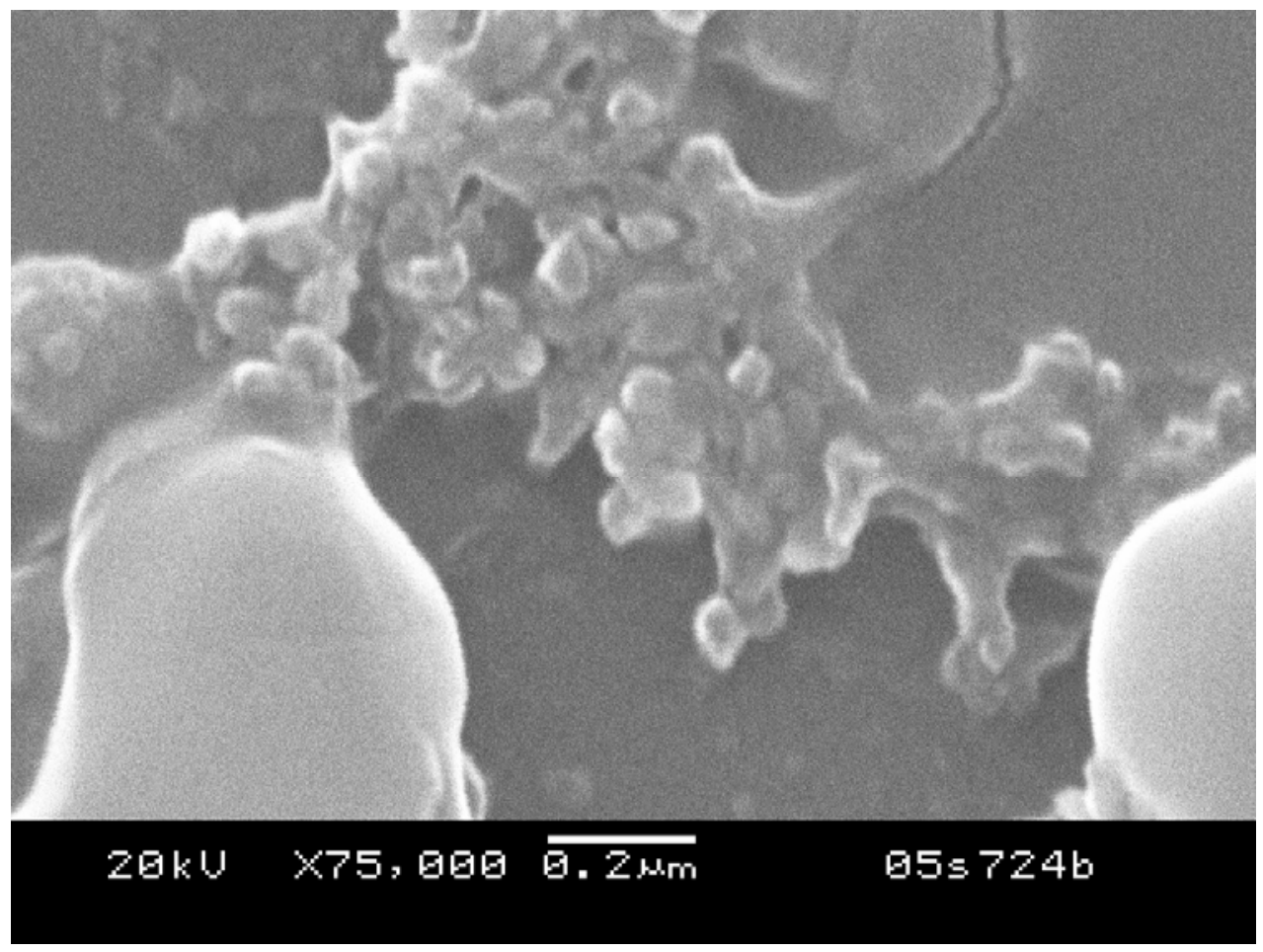

Figure 3. This is an Ormosil Procedure it didn't turn out very good at all.

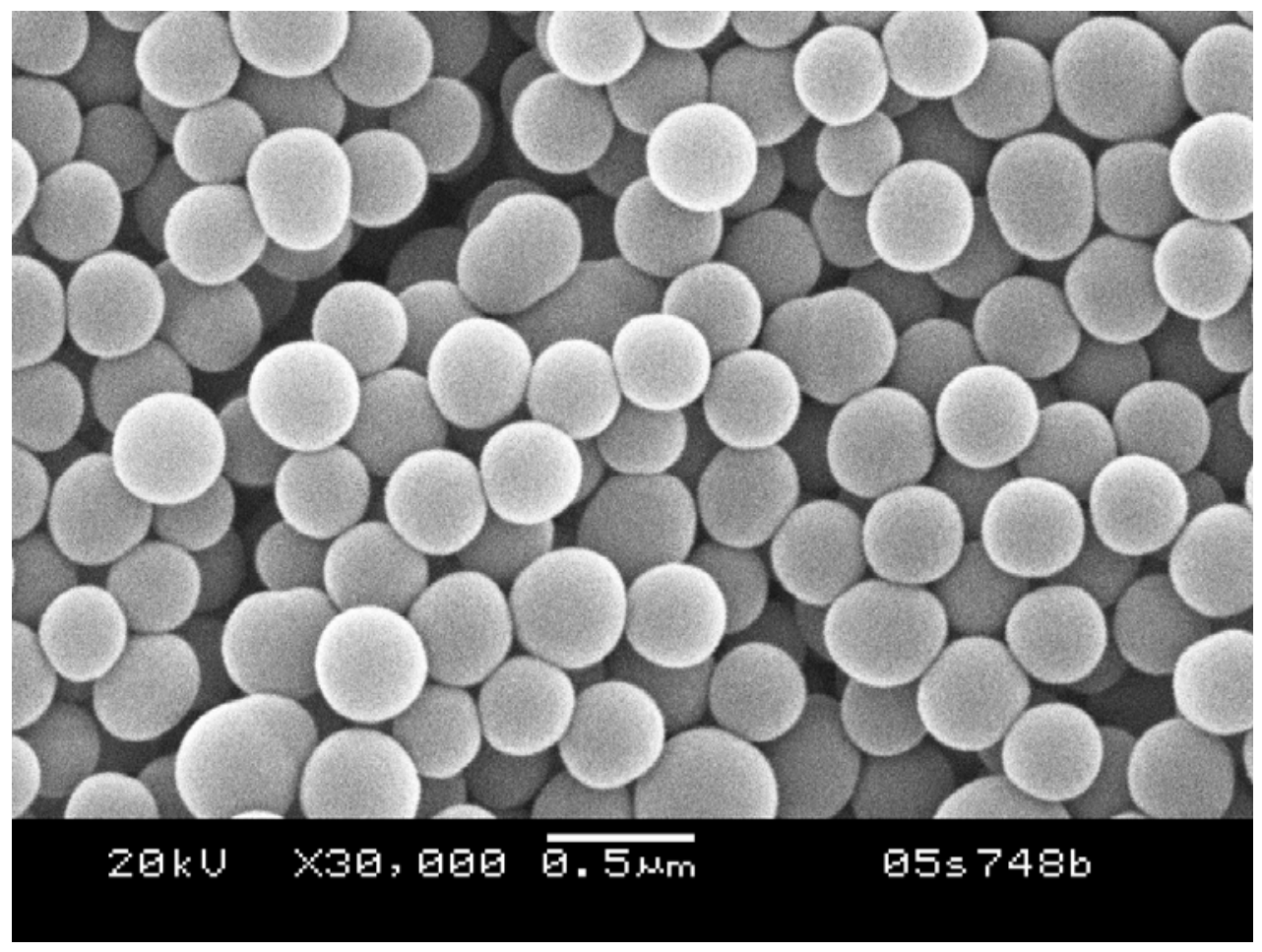

Figure 4. This Ormosil procedure displays perfect uniformity. 


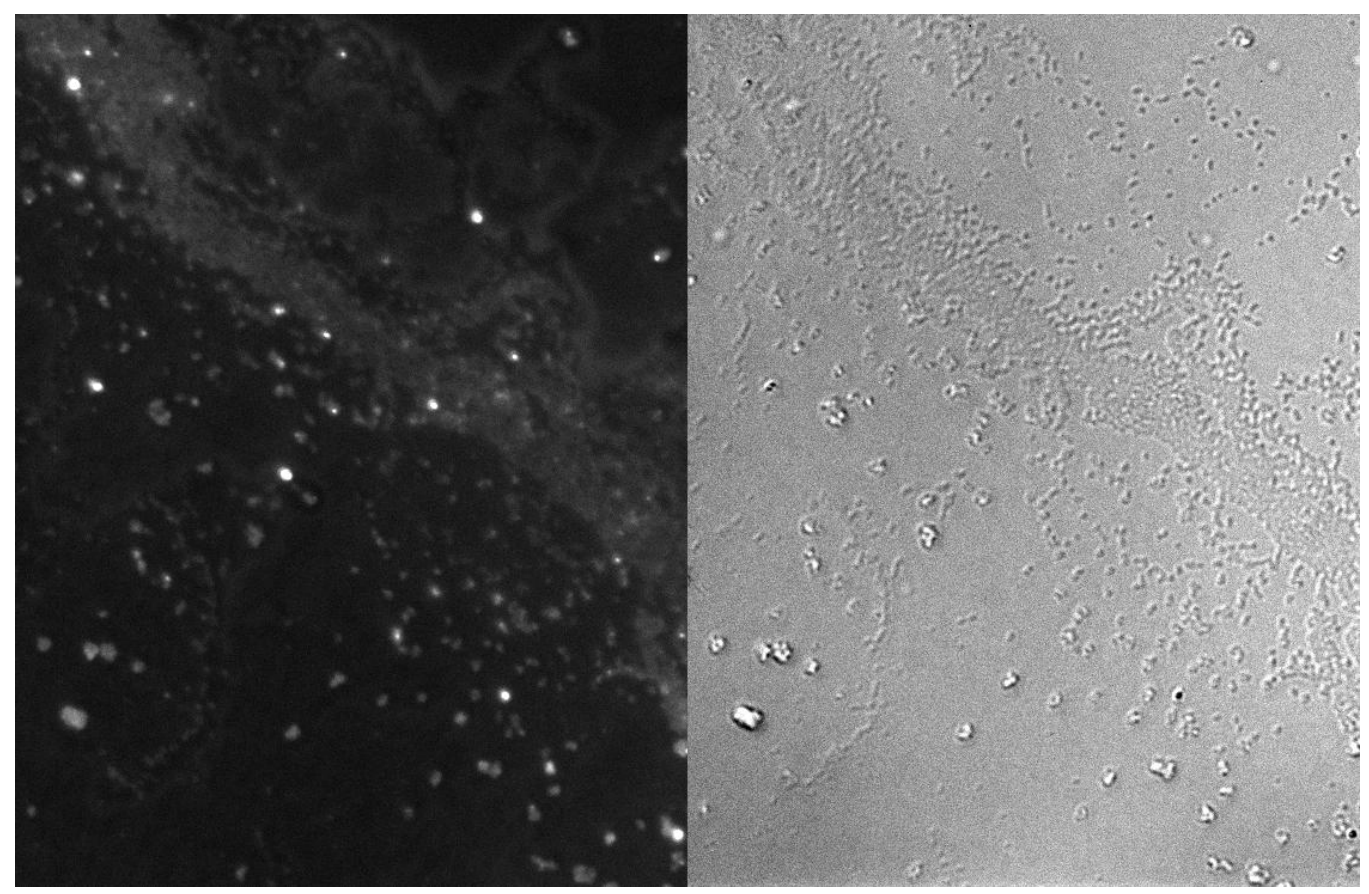

Figure 5. Pictures of actual particles that were taken off the filters to be tested on Biofilms. From the Sol - gel pebble procedure.

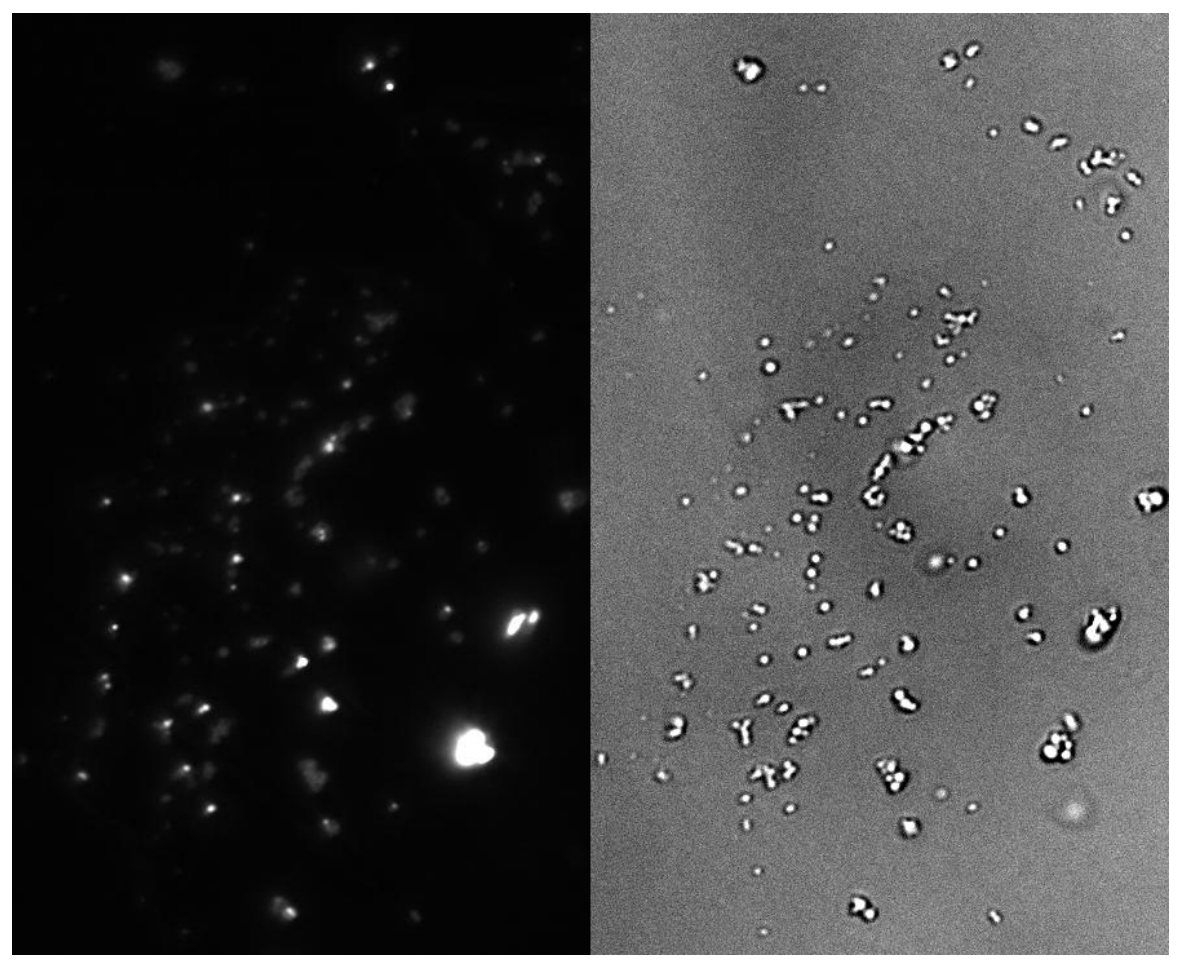

Figure 6. Another picture of the particles that were taken from the ultrafiltration filter from and ormosil procedure. 